\title{
Real-time monitoring of cadmium toxicity in rabbit kidney cells
}

\author{
Michal Milek ${ }^{1}$, Dana Marcinčáková2 ${ }^{2}$ Tomáš Csank³, Petra Kšonžeková3, Marcel Falis², \\ Jaroslav Legáth ${ }^{2}$, Juraj Pistl ${ }^{3}$
}

\begin{abstract}
${ }^{1}$ University of Technology, Department of Biochemistry and Biotechnology, Rzeszów, Poland ${ }^{2}$ University of Veterinary Medicine and Pharmacy in Košice, Department of Pharmacology and Toxicology, ${ }^{3}$ Department of Microbiology and Immunology, Košice, Slovak Republic
\end{abstract}

Received April 20, 2015

Accepted September 23, 2015

\begin{abstract}
The aim of this study was to investigate the toxic effect of the metal salt cadmium chloride dihydrate on the rabbit kidney cell line using the xCELLigence system or real-time cell analyser (RTCA), and to compare this relatively new method with standard biological cytotoxicity assays. This system provides real-time monitoring of cell behaviour and proliferative activity during the whole time of experiment. Moreover, after $24 \mathrm{~h}$ exposure of cells to cadmium, colorimetric 3-[4,5-dimethylthiazol-2-yl]-2,5-difenyl tetrazolium bromide (MTT) test was used to measure the metabolic activity and cytotoxicity was determined by measurement of lactate dehydrogenase $(\mathrm{LDH})$ leaked from damaged cells. We found that renal cells exposed to lower concentrations $\left(5-10 \mathrm{mg} \cdot \mathrm{l}^{-1}\right)$ of cadmium tend to grow similarly to control cells, however, cell index was significantly different $(P<0.05)$ after $24 \mathrm{~h}$. With increasing concentration of cadmium $(15-50$ $\left.\mathrm{mg} \cdot \mathrm{l}^{-1}\right)$ significantly lower proliferative $(P<0.05)$ and metabolic activity $(P<0.05)$ of cells was observed and cytotoxicity increased simultaneously $(P<0.001)$. In addition, we found that the real-time monitoring of the cell response was significantly correlated with commonly used biological methods for toxicity measurement, for MTT assay $\mathrm{R}^{2}$ was $0.9448(P<0.01)$ and for $\mathrm{LDH}$ assay $\mathrm{R}^{2}$ was $0.9466(P<0.01)$, respectively. The present study is the first report when combination of RTCA, MTT assay and LDH test was used for cadmium nephrotoxicity assessment. In all these methods, the toxic effect of cadmium on rabbit kidney cells increased in a concentration-dependent manner.
\end{abstract}

xCELLigence system, nephrotoxicity, cytotoxicity, lactate dehydrogenase

Increased industrial activities brought gradual redistribution of a number of toxic elements from the terrestrial crust into the environment and thus increased the potential exposure of humans and animals. With rising environmental pollution the interest arises in the consequences of the action of xenobiotics, including hazardous chemical elements, on live organisms (Nováková et al. 2007; Čelechovská et al. 2008). A series of trials were designed to evaluate the responses of tissues and organs of animal species of economic importance, such as the rabbit, to trace elements (cadmium, lead, mercury) at concentrations that could potentially exist in the feeds on a farm. The daily rations included carrots, potatoes, or beetroot. Cadmium belongs to heavy metals widely distributed in the environment, obtained as a by-product of refining. Its compounds are used in the electroplating of metals, alkaline batteries or in compounds with other metals. Relatively high quantities of cadmium are present in phosphate fertilisers (from some locations), which increase the concentration of cadmium in soil and plants. Cadmium is also highly toxic to organisms living in the aqueous environment (Koréneková et al. 2002). Because of its ability to reabsorb and accumulate divalent metals, kidney is the first target organ of heavy metal toxicity. The extent of renal damage depends on the nature, dose, route, and duration of exposure (Barbier et al. 2005). In toxicological studies cell cultures present a suitable substitute for living animal assays in preclinical tests of chemical substances. 
To determine the effect of various agents on the cells, the changes after exposition to the tested compounds are monitored, i.e. cells viability, proliferation, and apoptosis (Pan et al. 2012). In vitro cytotoxicity tests are routinely used for cytotoxicity effects induced by tested substances in various cell systems, obtained from different organs such as kidneys, liver, lungs, etc. These tests allow determining the effect of the given chemical substance on cells at a certain time, mostly at the end of the exposure of cells to the xenobiotic (endpoint analysis). Thus, only specific cell changes, not informing about biokinetics, dynamic interactions between the living cell and the toxic compound, are detected. Therefore, there is requirement for a detection assay without cell labelling, allowing a continuous monitoring of the state of cells and thereby providing information about the dynamics of cellular response to tested compound throughout the whole time of its exposure (Cerrioti et al. 2007).

The monitoring of the cells' response during the experiment is possible by using xCELLigence or Real-Time Cell Analyser - RTCA system (Acea Biosciences, Inc., Canada). This system monitors the adherence, distribution, proliferation, differentiation of cells, cytotoxicity caused by various substances, cell quality control, virus-mediated cytopathogenicity, migration and invasion of cells. Despite the obvious benefits of the xCELLigence system, further laboratory studies must be made in order to optimize evaluation of results obtained by this relatively new technology (Atienzar et al. 2013).

The aim of this work was to evaluate the toxic effect of the cadmium chloride on rabbit kidney RK13 cell line using real-time cell analyser (RTCA) and to compare this relatively new method with standard biological cytotoxicity assays. The MTT (3-[4,5-dimethylthiazol2-yl]-2,5-difenyl tetrazolium bromide) test was used to measure the metabolic activity of cadmium-exposed cells and the cytotoxicity was determined by measurement of lactate dehydrogenase leaked from damaged cells (LDH test).

\section{Materials and Methods}

\section{Chemicals}

The metal salt cadmium chloride dihydrate $-\mathrm{CdCl}_{2} \cdot 2 \mathrm{H}_{2} \mathrm{O}$ of analytical grade (Sigma Aldrich, Germany) was tested in this study. Stock solutions of metal salt were diluted in dimethylsulphoxide (DMSO, Lachema Brno Czech Republic). The concentration range was selected on the basis of works published earlier (Wätjen et al. 2002; Xing et al. 2006) as well as based on our preliminary studies.

\section{Cell culture and treatment}

RK13 (rabbit kidney cells) cell line was obtained from the European collection of cell culture. Cells were cultured in $75 \mathrm{~cm}^{2}$ cell culture flasks in minimal essential medium (EMEM - Earl's Minimal Essential Medium; Lonza, Belgium), supplemented with $10 \%$ foetal bovine serum (FBS; Lonza, Belgium) in a humidified atmosphere of $5 \% \mathrm{CO}_{2}, 95 \%$ air at $37{ }^{\circ} \mathrm{C}$. The passage number range was maintained between 20 and 25 . In the experiments, the cells were cultured in complete cultivation medium with $1 \%$ DMSO. Initial cell seeding density was optimised using the xCELLigence system before experiments. The solvent used in our study, DMSO at a final concentration $1 \%$, did not affect the metabolic and proliferative activity of the RK13 cell line.

xCELLigence system - Real-Time Cell Analyser (RTCA)

The RTCA system was described by many authors (Xing et al. 2006; Ceriotti et al. 2007; Slanina et al. 2011; Garcia et al. 2013). It utilizes a series of micro wells with bottoms covered by $80 \%$ with microelectrodes that measure cell viability by monitoring cell proliferation and morphology. The monitoring uses a dimensionless unit called the cell index (CI) which is based on the impedance changes caused by cells interacting with microelectrodes. Analysis of cell proliferation was performed according to the manufacturer's instructions (Acea Biosciences, Inc., Canada).

Briefly, $100 \mu$ l of cell medium was added into 16-well E-plates (Roche, Applied Science, Mannheim, Germany) for background measurement. Subsequently, $1.5 \times 10^{4}$ cells/well in $50 \mu 1$ of cell culture medium supplemented with $1 \%$ DMSO were seeded in 16-well E-plates inserted into $16 \times$ plate station, which was kept inside a $\mathrm{CO}_{2}$ incubator at $37{ }^{\circ} \mathrm{C}$ with $5 \% \mathrm{CO}_{2}$. After $20 \mathrm{~h}$ when cells were subconfluent and remaining within a log phase, the cadmium was added to the cells at final concentrations of $5,10,15,20,50 \mathrm{mg} \cdot \mathrm{l}^{-1}$. Wells without cadmium exposure served as control. Treated and control cells were incubated for $48 \mathrm{~h}$ ( $68^{\text {th }}$ hour of experiment $)$ and CI was measured automatically by the RTCA system once per hour until the end of the experiment. Proliferative activity in percentage expression was calculated according to the equation: $\% \mathrm{PA}=\mathrm{CI}_{\text {cadmium }} \times 100 / \mathrm{CI}_{\text {control }}$. 
Cytotoxicity LDH leakage assay

Cells were seeded in a 96-well culture plate (Greiner, Sigma Aldrich, Germany) at a density of $2.2 \times 10^{4}$ cells/well in $100 \mu \mathrm{l}$ of cell culture medium and incubated in a $\mathrm{CO}_{2}$ incubator at $37{ }^{\circ} \mathrm{C}$ with $5 \% \mathrm{CO}_{2}$. After $20 \mathrm{~h}$ of cultivation, the cells were exposed to cadmium at final concentrations of $5,10,15,20,50 \mathrm{mg} \cdot \mathrm{l}^{-1}$. After the $24 \mathrm{~h}$ exposure period, colorimetric assay was used to quantify cytotoxicity/cytolysis by measuring LDH activity released from damaged cells only (Cytotoxicity Detection Kit, Roche Diagnostics, Germany). Briefly, the cells were incubated with a reaction mixture for $30 \mathrm{~min}$ at room temperature. Subsequently, the reaction was stopped and optical density (OD) was measured at $450 \mathrm{~nm}$ using Synergy HT (USA). To calculate cytotoxicity (\%) in each plate, low control (LC) and high control (HC) were set up and the percentage of cytotoxicity (C) was calculated according to the equation: $\% \mathrm{C}=\mathrm{OD}_{\text {cadmium }}-\mathrm{OD}_{\mathrm{LC}} / \mathrm{OD}_{\mathrm{HC}}-\mathrm{OD}_{\mathrm{LC}} \times 100$, where $\mathrm{OD}_{\text {cadmium }}$ is the mean $\mathrm{OD}$ value of cells treated with heavy metal, $\mathrm{OD}_{\mathrm{LC}}$ (low control) is the mean OD value of cells treated with the solvent control $\left(1 \% \mathrm{DMSO}\right.$ ) and $\mathrm{OD}_{\mathrm{HC}}$ (high control) is the mean OD value of cells treated with the lysis buffer (the maximum releasable LDH activity) measured at $450 \mathrm{~nm}$.

\section{MTT reduction assay}

The MTT test is based on the cellular uptake of 3-[4,5-dimethylthiazol-2-yl]-2,5-difenyl tetrazolium bromide and its subsequent reduction in the mitochondria of living cells to a dark, water insoluble, and blue formazan. Cells without metabolic activity are almost completely negative for this cleavage activity (Mossmann 1983; Tan et al. 2008). For MTT test, RK13 cells were seeded in standard 96-well microtitre plates at a density $2.2 \times 10^{4}$ cells/well. The cells were incubated with cadmium $\left(5-50 \mathrm{mg} \cdot \mathrm{l}^{-1}\right)$ in culture medium supplemented with $1 \%$ DMSO for $24 \mathrm{~h}$ at $37{ }^{\circ} \mathrm{C}$ in a fully humidified atmosphere under $5 \% \mathrm{CO}_{2}$. After incubation, culture medium was refreshed and MTT $\left(0.5 \mathrm{mg} \cdot \mathrm{l}^{-1}\right)$ was added to cells. The cells were incubated for additional $4 \mathrm{~h}$ in the dark. Formazan crystals were solubilised using concentrated DMSO, and Sorensen's glycine buffer $\left(0.1 \mathrm{mg} \cdot 1^{-1}\right.$ glycine, $\left.0.1 \mathrm{mg} \cdot 1^{-1} \mathrm{NaCl}, \mathrm{pH} 10.5\right)$ was added for stabilisation of the final product. Absorbance was recorded at $570 \mathrm{~nm}$ using a microplate reader (Synergy HT; Biotek, Winooski, VT, USA). The metabolic activity ( $\%$ ) of treated cells was calculated with respect to control cells, according to the equation: $\% \mathrm{MA}=\mathrm{OD}$ $\times 100 / \mathrm{OD}$

\section{Statistical analysis}

Data were analyzed by GraphPadPrism 3.0 using ANOVA, followed by Dunnett's test. Results are expressed as mean $\pm \mathrm{SD}(\mathrm{n}=3), P<0.05$ was considered to be significant. The correlation coefficients $\left(\mathrm{R}^{2}\right)$ between RTCA, LDH, and MTT tests were calculated using Pearson's test.

\section{Results}

For RTCA study, the RK13 cells were exposed to cadmium for $48 \mathrm{~h}$ and CI was measured automatically every hour until the end of the experiment. Figure 1 shows RTCA curves (CI vs. exposure time) that clearly demonstrate the concentration-dependent toxic effect of cadmium on RK13 cells. Cells treated with lower concentrations of cadmium $\left(5,10 \mathrm{mg} \cdot \mathrm{l}^{-1}\right)$ tended to grow similarly to control cells; however, significantly decreased CI values after $24 \mathrm{~h}$ treatment of RK13 cells with cadmium at a concentration of $5 \mathrm{mg} \cdot \mathrm{l}^{-1}(P<0.05$; Table $1)$, as well as $10 \mathrm{mg} \cdot \mathrm{l}^{-1}$ was observed $(P<0.001$; Table 1$)$. The highest tested concentration of cadmium $\left(50 \mathrm{mg} \cdot \mathrm{l}^{-1}\right)$ reduced CI values to zero in the first few hours of treatment,

Table 1. Effect of cadmium on proliferation, metabolic activity and cell damage of RK13 cells after $24 \mathrm{~h}$ treatment.

\begin{tabular}{lcccccc}
\hline \multicolumn{5}{c}{ Concentrations of cadmium $\left(\mathrm{mg} \cdot 1^{-1}\right)$} \\
\cline { 2 - 7 } & 5 & 10 & 15 & 20 & 50 & Control \\
\hline CI & $1.86 \pm 0.06^{*}$ & $1.79 \pm 0.03^{* * *}$ & $0.66 \pm 0.13^{* * *}$ & $0.21 \pm 0.02^{* * *}$ & $0.01 \pm 0.00^{* * *}$ & $2.09 \pm 0.01$ \\
PA & $89.05 \pm 2.64$ & $85.83 \pm 1.40$ & $31.8 \pm 6.41$ & $10.22 \pm 1.25$ & $0.38 \pm 0.06$ & - \\
OD & $1.15 \pm 0.04^{*}$ & $0.9 \pm 0.16^{* *}$ & $0.39 \pm 0.23^{* * *}$ & $0.20 \pm 0.02^{* * *}$ & $0.02 \pm 0.00^{* * *}$ & $1.20 \pm 0.07$ \\
MA & $95.38 \pm 3.95$ & $74.60 \pm 16.67$ & $32.53 \pm 2.41$ & $17.12 \pm 1.60$ & $1.88 \pm 0.34$ & - \\
OD & $1.35 \pm 0.02^{* * *}$ & $1.40 \pm 0.03^{* * *}$ & $1.94 \pm 0.06^{* * *}$ & $2.64 \pm 0.07^{* * *}$ & $2.81 \pm 0.01^{* * *}$ & $1.00 \pm 0.03$ \\
C & $14.08 \pm 0.96$ & $16.15 \pm 1.20$ & $37.26 \pm 2.51$ & $65.40 \pm 2.65$ & $72.22 \pm 0.22$ & - \\
\hline
\end{tabular}

$\mathrm{CI}$ - cell index, PA - proliferative activity (\%), OD - optical density (nm), MA - metabolic activity (\%), $\mathrm{C}-$ cytotoxicity $(\%)$

Results are expressed as mean value \pm standard deviation $(\mathrm{n}=3) ;{ }^{* * *} P<0.001 ;{ }^{* *} P<0.01 ;{ }^{*} P<0.05$ 
i.e. no viable cells were attached to the microelectrodes, indicating the highest cytotoxicity, or effect on cell behaviour.

Based on the RTCA curves, the optimal time for MTT and LDH assay was selected at the $24^{\text {th }} \mathrm{h}$ of cell exposure to cadmium. Results of LDH, MTT and RTCA tests after $24 \mathrm{~h}$ cell exposure to cadmium are shown in Table 1. For clearer expression the results are calculated to \% with respect to the control cells exposed to the solvent only. With an increase of cadmium concentration, lower proliferative and metabolic activity of cells was observed $(P<0.05)$ and simultaneously, cytotoxicity increased $(P<0.001)$.

The results of real-time cell analysis (RTCA) expressed as a percentage of control showed significant correlation $\left(\mathrm{R}^{2}=0.9448 ; P<0.01\right)$ with viability of cells determined with MTT test. Similar correlation was observed between RTCA and LDH assay $\left(\mathrm{R}^{2}=0.9466\right.$; $P<0.01)$ and slightly lower between MTT and LDH test $\left(\mathrm{R}^{2}=0.8933 ; P<0.05\right)$. Correlations of RTCA method with MTT and LDH test are shown in Table 2.

Table 2. Comparison of RTCA method with MTT and LDH tests.

\begin{tabular}{lrrrr}
\hline \multirow{2}{*}{ Cadmium $\left(\mathrm{mg} \cdot \mathrm{l}^{-1}\right)$} & \multicolumn{2}{c}{ MTT } & \multicolumn{2}{c}{ LDH } \\
\cline { 2 - 5 } & \multicolumn{1}{c}{$P$} & $\mathrm{R}^{2}$ & \multicolumn{1}{c}{$\mathrm{R}^{2}$} \\
\hline 5.0 & 0.0238 & 0.7590 & 0.3125 & 0.2500 \\
10.0 & 0.0029 & 0.9134 & $<0.0001$ & 1 \\
15.0 & $<0.0001$ & 0.9996 & $<0.0001$ & 1 \\
20.0 & 0.0004 & 0.9678 & $<0.0001$ & 1 \\
50.0 & 0.2235 & 0.3412 & 0.2556 & 0.3052 \\
\hline
\end{tabular}

$\mathrm{R}^{2}-$ Pearson's R square coefficient, $P-P$ value; RTCA (Real-Time Cell Analyser); MTT -

(3-[4,5-dimethylthiazol-2-yl]-2,5-difenyl tetrazolium bromide; $\mathrm{LDH}$ - lactate dehydrogenase

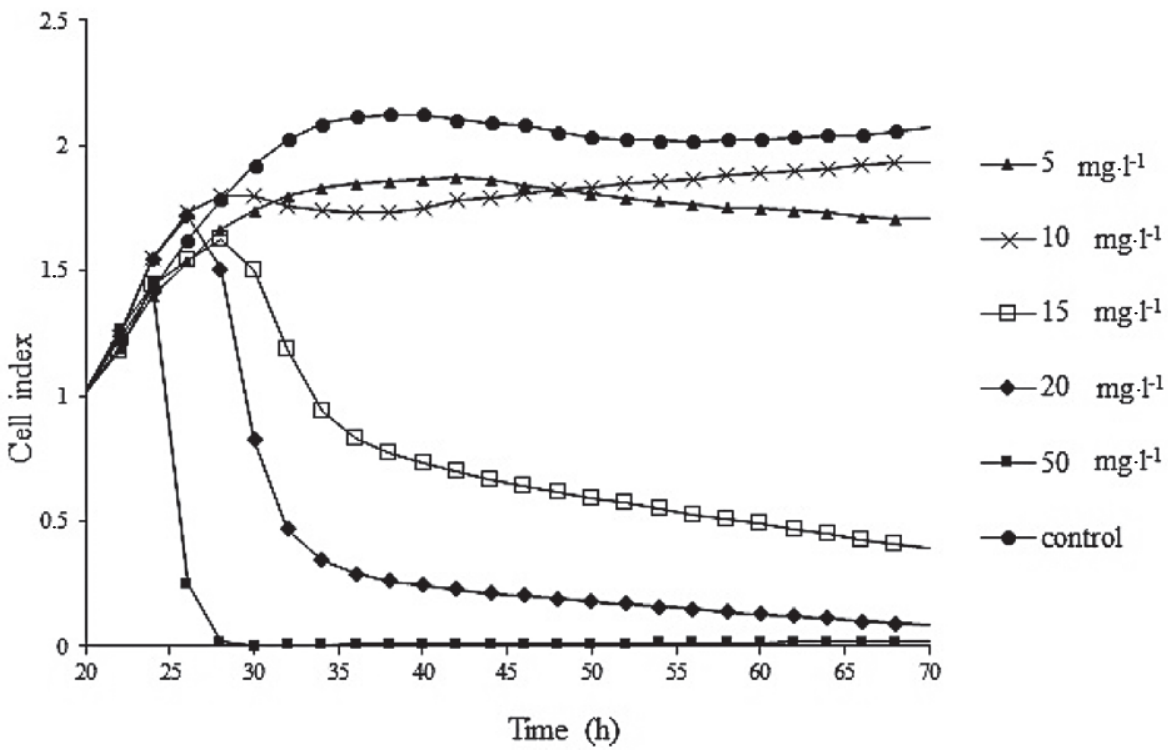

Fig. 1. Dynamic changes in the cell index of RK13 cells during a $48 \mathrm{~h}$ exposure to cadmium. Results are expressed as means $(n=3)$. 


\section{Discussion}

Cadmium is a highly toxic and carcinogenic environmental contaminant. Exposure to cadmium is most commonly associated with tobacco smoke, contaminated food and the environment (Bernard 2008). It presents a serious hazard to animal health and a threat to most life forms. Element toxicity to biological systems of animals is affected by the route and form of ingestion as well as by the interaction between essential and toxic elements. The amount of an element that accumulates in the organs depends on the interval of exposure, the quantity ingested and the production, as well as the animal's age and species (Massányi et al. 2005; Koréneková et al. 2002).

On the cellular level cadmium may lead to cell death via apoptosis as well as necrosis. The mechanisms of cadmium-induced apoptosis include mitochondrial membrane breaking, DNA fragmentation and chromosomal changes (Wätjen et al. 2002). It accumulates in mitochondria, where it blocks the respiratory chain at complex III resulting in an increased production of free radicals which enhances caspase activity leading to apoptosis. This metal could be the cause of various pathological states such as glycosuria, aminoaciduria, bicarbonaturia or phosphaturia, and may lead to inflammatory states and consequently to renal cancers (Bernard 2008).

In our work, the xCELLigence system for dynamic real-time monitoring of cell response after cadmium exposure was used. Continuous monitoring of cell changes such as adherence, proliferation, morphology, and cytotoxicity throughout the whole exposure to tested compound provides information about the best time for cytotoxicity testing. On the basis of CI changes the system allows to specify the optimal time of exposition to tested compound for further cytotoxic tests with various biological methods. It sets the time when the cytotoxic effect reached its maximum, and it saves time and material costs in the case of re-testing, because the testing of various concentrations and exposition intervals is necessary.

The growth curves of RK13 cells exposed to cadmium for $48 \mathrm{~h}$ show that with the increase of cadmium concentration, significantly decreased CI was observed $(P<0.05)$. It indicates that there was a reduction in the number of cells adhered to the plates and the loss of adherence may indicate the upcoming death of adherent cells. On the other hand, decreased CI is not always connected with toxicity, thus the results may be misleading in some circumstances (Atienzar et al. 2013). Therefore, the cytotoxic action of tested substances should be verified with several different methods. In this paper, colorimetric MTT test was used for determination of the metabolic activity of cadmium-exposed cells. Significantly reduced metabolic activity in comparison to solvent-treated control cells was observed in all tested concentrations of the cadmium $(P<0.05)$, which is in correlation with RTCA $\left(\mathrm{R}^{2}=0.9448, P<0.01\right)$. The suitability of the use of RTCA in combination with MTT test for toxicity measurement was also confirmed by Xing et al. 2006. Cadmium-induced nephrotoxicity was also assessed by LDH leakage into the culture medium. The LDH leakage assay has been employed as an indicator of cytotoxicity in liver cells (Dong et al. 1998; Fotakis and Timbrell 2006) as well as in toxicity studies using rat renal proximal tubular cells (Fukumoto et al. 2001) and rabbit kidney epithelial cells (Pollakova et al. 2012). The loss of intracellular LDH and its release into the culture medium is an indicator of irreversible cell death due to cell membrane damage (Fotakis and Timbrell 2006). In our work, we observed that the amount of released LDH from cadmium-exposed RK13 cells increased in a concentration-dependent manner. Cytotoxicity of cadmium was also confirmed on hepatic cells (Dong et al. 1998; Fotakis and Timbrell 2006).

The present study is the first report when combination of RTCA, MTT assay and LDH test was used for cadmium nephrotoxicity assessment. In summary, we found that cadmium has an increasing toxic effect on the rabbit kidney RK13 cell line in a concentration-dependent 
manner. Moreover, RTCA in combination with other commonly used biological methods provides significant, correlating results about cadmium nephrotoxicity.

\section{Acknowledgement}

This work was supported by National Reference Laboratory for Pesticides of University of Veterinary Medicine and Pharmacy in Košice and Vega Project No. 1/0855/12.

\section{References}

Atienzar FA, Gerets H, Tilmant K, Toussaint G, Dhalluin S 2013: Evaluation of impedance-based label-free technology as a tool for pharmacology and toxicology investigations. Biosensors 3: 132-156

Barbier O, Jacquillet G, Tauc M, Cougnon M, Poujeol P 2005: Effect of heavy metals on, and handling by, the kidney. Nephron Physiol 99: 105-110

Bernard A 2008: Cadmium \& its adverse effects on human health. Indian J Med Res 128: 557-564

Boyd JM, Huang L, Xie L, Moe B, Gabos S, Xing-Fang L 2008: A cell-microelectronic sensing technique for profiling cytotoxicity of chemicals. Anal Chim Acta 615: 80-87

Ceriotti L, Ponti J, Broggi F, Kob A, Drechsler S, Thedinga E, Colpo P, Sabbioni E, Ehret R, Rossi F 2007: Realtime assessment of cytotoxicity by impedance measurement on a 96-well plate. Sens Actuators B 123: 769-778

Čelechovská O, Malota L, Zima S 2008: Entry of heavy metals into food chains: a 20-year comparison study in Northern Moravia (Czech Republic) Acta Vet Brno 77: 645-652

Dong W, Simeonova PP, Gallucci R, Matheson J, Flood L, Wang S, Hubbs A, Luster IM 1998: Toxic metals stimulate inflammatory cytokines in hepatocytes through oxidative stress mechanisms. Toxicol Appl Pharmacol 1551: $359-366$

Fotakis G, Timbrell JA 2006: In vitro cytotoxicity assays: comparison of LDH, neutral red, MTT and protein assay in hepatoma cell lines following exposure to cadmium chloride. Toxicol Lett 160: 171-177

Fukumoto M, Kujiraoka T, Hara M, Shibasaki T, Tatsuo H, Yoshida M 2001: Effect of cadmium on gap junctional intercellular communication in primary cultures of rat renal proximal tubular cells. Life Sci 69: 247-254

Garcia SN, Gutierrez L, McNulty A 2013: Real-time cellular analysis as a novel approach for in vitro cytotoxicity testing of medical device extracts. J Biomed Mater Res Part A 101A: 2097-2106

Koréneková B, Skalická M, Nad' P 2002: Cadmium exposure of cattle after long-term emission from polluted area. Trace Elem Electrolytes 19: 97-99

Massányi P, Uhrín V, Toman R, Pivko J, Lukáč N, Forgács Zs, Somosy Z, Fabiš M, Danko J 2005: Ultrastructural changes of ovaries in rabbits following cadmium administration. Acta Vet Brno 74: 29-35

Mossman T 1983: Rapid colorimetric assay for cellular growth and survival: application to proliferation and cytotoxicity assays. J Immunol Methods 65: 55-63

Nováková J, Daňová D, Strišková K, Hromada R, Mičková H, Rabišková M 2007: Zinc and cadmium toxicity using a biotest with Artemia franciscana. Acta Vet Brno 76: 635-642

Pan TH, Huang B, Xing JZ, Zhang WP, Gabos S, Chen J 2012: Recognition of chemical compounds in contaminated water using time-dependent multiple dose cellular responses. Anal Chim Acta 724: 30-39

Pollakova J, Kovalkovičová N, Csank T, Pistl J, Košišová A, Legáth J 2012: Evaluation of bendiocarb cytotoxicity in mammalian and insect cell cultures. J Environ Sci Heal B 47: 538-543

Slanina H, König A, Claus H, Frosch M, Schubert-Unkmeir A 2011: Real-time impedance analysis of host cell response to meningococcal infection. J Microbiol Methods 84: 101-108

Tan F, Wang M, Wang W, Lu Y 2008: Comparative evaluation of the cytotoxicity sensitivity of six fish cell lines to four heavy metals in vitro. Toxicol In Vitro 22: 164-170

Wätjen W, Haase H, Biagioli M, Beyersmann D 2002: Induction of apoptosis in mammalian cells by cadmium and zinc. Environ Health Perspect 110: $865-867$

Xing JZ, Zhu L, Gabos S, Xie L 2006: Microelectronic cell sensor assay for detection of cytotoxicity and prediction of acute toxicity. Toxicol In Vitro 20: 995-1004 